\title{
RICH MEDIA MOBILE ADVERTISING: COMPARISON OF GESTURES USED FOR NAVIGATION THROUGH A PHOTO GALLERY
}

\author{
Robert Sedov̌̌ek, Matevž Pogačnik, Aleš Hladnik
}

Original scientific paper

The aim of this paper was to get an insight into user's preferences over different interactions with mobile ads. In particular, we were interested whether the users prefer swiping or tapping while navigating through a photo gallery. A correlation between the user interface and user engagement (the number of photos viewed) was analysed. A subset of users were also shown a coach notice with an information about how to navigate to examine whether coach notices can improve user experience by reducing usability issues. To answer these questions we developed a tracking system to analyse behaviour of 633 users and performed a survey on 46 people. The results show that swiping is preferable to tapping when navigating through the gallery and that the navigation mode does have an impact on the number of photos viewed. We were also able to show that the presence of a coach notice decreased the number of faulty gestures, but suggested a further work to maximize its potential.

Keywords: photo gallery; rich media mobile advertising; user gestures; user interface

Bogato oglašavanje putem mobilnih medija: usporedba pokreta rabljenih u navigaciji kroz foto galeriju

Izvorni znanstveni članak

Cilj ovoga članka je ustanoviti preferencije korisnika u različitim interakcijama s obavijestima na prenosivom telefonu. Posebno nas je zanimalo da li korisnici više vole potezanje prstom (swiping) ili kuckanje (tapping) dok pregledavaju foto galeriju. Analizirala se korelacija između korisnikovog sučelja i angažmana (broja pregledanih fotografija). Dijelu korisnika je također pokazana obavijest s uputstvom kako postupati da bi se ustanovilo je li smanjenje mogućnosti izbora poboljšava korisnikovu funkcionalnost. Kako bismo odgovorili na ova pitanja razvili smo sustav praćenja u svrhu analize ponašanja 663 korisnika i anketirali 46 korisnika. Rezultati pokazuju da kod pregledavanja galerije potezanje prstom ima prednost pred kuckanjem i da način navigacije uistinu utječe na broj pregledanih fotografija. Također smo mogli pokazati da je postojanje upute smanjilo broj pogrešnih pokreta, ali smo predložili daljnje istraživanje kako bi se potpuno iskoristio njen potencijal.

Ključne riječi: bogato oglašavanje putem mobilnih medija; foto galerija; pokreti korisnika; sučelje korisnika

\section{Introduction}

The number of mobile devices, such as phones, tablets, watches and e-readers is growing rapidly and so are their hardware features (compass, camera, GPS, gyroscope etc.), enabling richer activities and interactions. Mobile phones are available within a wide price range and are being ubiquitously carried around in pockets by several million individuals. Their usage has increased [1], which influenced ergonomics of software design [2] and introduced new ways of interaction, such as using voice as an input and a variety of touch gestures: swipe, tap, drag, pinch, shake, and others.

Rich media mobile advertising, compared to other mobile advertising formats, such as text messaging ads, search ads, audio ads and static media display ads, offers highly customizable mobile ad creatives. Designers and developers can benefit from using HTML, CSS, JavaScript and other open web standard technologies that enable richer interactions and offer numerous possibilities that ads can benefit from, including, but not limited to: embedding a video or audio, autoplay animations, touch interactions integration, use of a camera, gyroscope, accelerometer, GPS. Rich media ads that take advantage of these capabilities can offer novel interactions users have with an ad, present a game-like experience, take advantage of user's GPS to list nearest advertised stores, include a video presentation or present user with a photo gallery of advertised items.

In the presented study two of the most commonly utilized navigation gestures - swipe and tap - when browsing through a simple photo gallery were investigated. In particular, we wanted to compare the intuitiveness of the two gestures, investigate the impact of the user interface's (UI) intuitiveness on the number of gallery photos viewed and study the effect of a coach notice on the correct or faulty use of UI.

\subsection{User interface and user experience in mobile advertising}

Numerous factors are related to the user experience when a user interacts with his/her mobile phone or tablet. Some of the most important ones are the ability to evoke positive feelings [3], accessibility [4], aesthetic appeal [5,

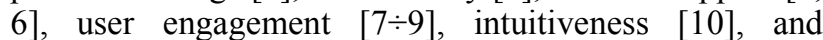
familiarity [11]. A better UI has usability advantages [12], higher completion rates, and other benefits [9]. In marketing, advertisers are trying hard to attract users' attention and increase their retention, either through prolonged time spent on an ad, increased number of content views (pages, photos, etc.), actions performed or/and anything else that has a potential to result in a marketing lift. Because the money spent on advertising is rapidly increasing - mobile advertising in 2014 totalled $\$ 7,1$ billion and accounted for $25 \%$ of the year's online advertising revenues in the United States alone [13] there is an increased demand for better designed ads to maximize their potential.

When it comes to designing appropriate UIs, especially for the mobile smartphones, context-dependent situations are taken into consideration and distractions play a significant role. Negulescu et al. [14] compared tap, swipe and move gestures as an input and found no significant differences in reaction times for motion gestures, taps, or surface gestures on smartphones in two specific scenarios: a walking scenario, and an eyes-free seated scenario. In another study tap- and swipe-based 
interaction design patterns for older adults were studied [15], where in most cases, the majority of participants were not familiar with the UI and were not able to solve tasks, but after being exposed to a guided interactive tutorial, they could easily learn how to perform tasks by either using swipe or tap.

\section{Methodology}

Our study investigated the intuitiveness of UI, its impact on user engagement - i.e. the number of photos viewed - and the usability issues - the amount of faulty gestures - users had while interacting with a mobile gallery. A challenge was to test users' behaviour without them being aware of participating in the research. Due to the complex nature of a context-dependent mobile environment $[16,14]$, we wanted to test users' behaviour and ways of interaction in their natural habitat and not in a controlled laboratory environment, where usability tests are traditionally performed $[17 \div 19]$. Doing a research on a larger scale [20] and cost effectiveness [21] were also important motivating factors.

Hardware and software components of the system that was developed for the study were as follows:

- advertisement, which was built using Google AdWords [22],

- application (client-side software): a mobile photo gallery that was equipped with an analytical tracking software,

- HTTP server to run the application and serve it to the users,

- $\quad$ server-side tracker: a lightweight tracker to write $\log$ files to the system,

- $\quad \log$ analysis: node.js and a batch of known Unix tools to parse $\log$ files.

Individual elements of the study workflow, shown in Fig.1, are explained below.

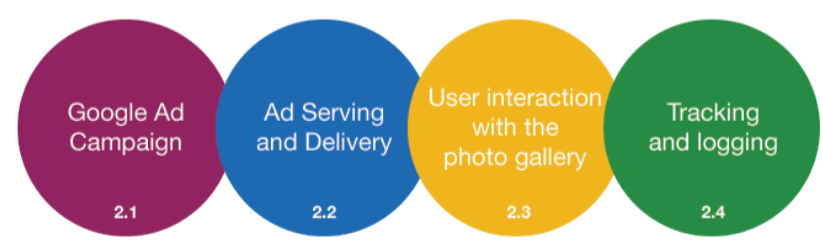

Figure 1 Experimental workflow

\subsection{Google ad campaign}

Google services were used to setup a campaign, create an ad, and to deliver it to the targeted users. The users that clicked on an ad and interacted with it were participating in a remote usability test without being aware of their participation. Campaign details are presented in Tab. 1.

The targeted group were English speaking smartphone owners (Android 4.0+ or iPhone iOS7+), connected through WiFi (to ensure a reliable connection), targeted via Google AdWords [22]. The campaign was run for four days and it was served to the banner placement categories, such as entertainment, health \& fitness, lifestyle and photography, using Google Display Network, with the ability to serve ads to mobile banner placements on Gmail, Blogger, YouTube and multiple other websites that show relevant Google ads.

Table 1 Campaign details

\begin{tabular}{|l|r|}
\hline \multicolumn{2}{|c|}{ Impressions * } \\
\hline Clicks on ad & 435976 \\
\hline Click-Through Rate (CTR) & 3318 \\
\hline Impressions with activity** & $0,76 \%$ \\
\hline Impressions with either tap or swipe gestures & 633 \\
\hline Impressions without any activity & 574 \\
\hline * an impression represents an ad which is served to a user's browser \\
** at least one user initiated action (tap, swipe, pinch, zoom, etc.) was recorded
\end{tabular}

\subsection{Ad serving and delivery}

The targeted users were shown a typical ad (Fig. 2) that was designed, built and distributed via Google AdSense [22] services.

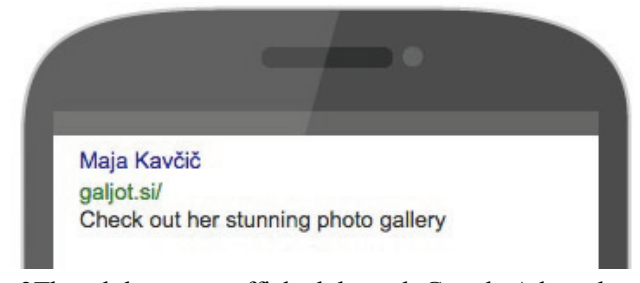

Figure 2The ad that was trafficked through Google Ads and served to multiple banner placement categories

\subsection{User interaction with the photo gallery}

The central part of the study consisted of two independent experiments. In the first one, a mobile user tapped on the ad (Fig. 2), upon which the gallery of six high resolution photographs chosen from the model's personal archive opened. The first photo appeared immediately after clicking the ad and the user was allowed to navigate to see other photos. Using open web technologies (HTML, CSS and JavaScript), the gallery was built so that it systematically served to the user one of the two possible UIs:

- $\quad$ "Tappy UI": user needed to tap on the left/right-hand side of the screen to see previous/next photo.

- $\quad$ "Swipey UI": user had to swipe to the left/right to see previous/next photo.

In addition, in about half of the sessions, a coach notice (Fig. 3) was added to the first image in the series. The coach notice instruction gave the user a clear message which of the two gestures should be used for browsing through the gallery, while in the sessions without the coach notice it was up to the user to figure out which gesture is required to navigate through the gallery. Consequently, there were altogether four possible versions served to the users: Tappy UI without a coach notice, Tappy UI with a coach notice, Swipey UI without a coach notice, Swipey UI with a coach notice.

The second experiment was a simple on-line crowdsourced survey where users -46 in total - were asked which is their preferred gesture for mobile photo gallery navigation: swipe or tap (Fig. 4). Its purpose was to examine possible correlation between the logged data from the first experiment and the answers acquired from the on-line survey. 


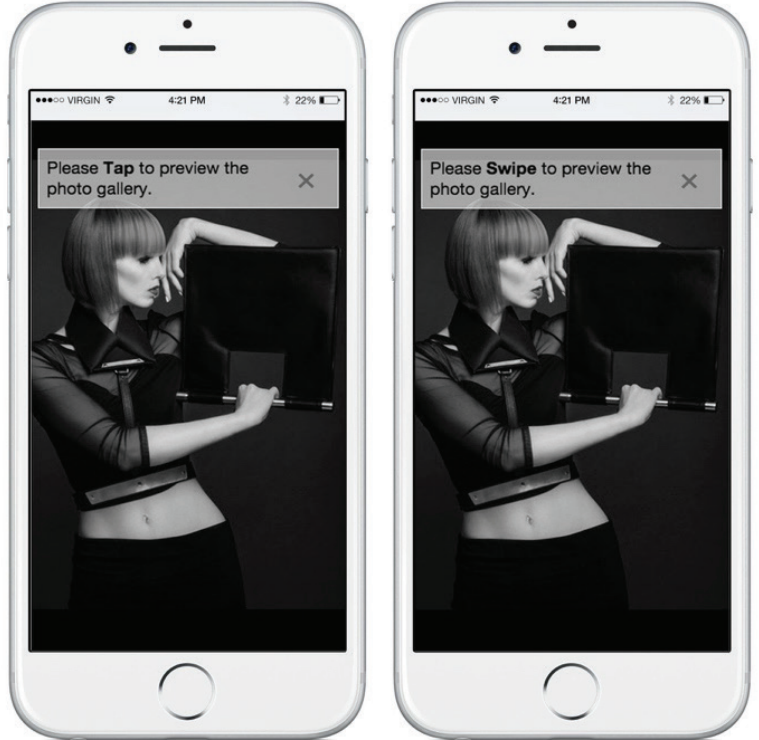

Figure 3 One of the six mobile gallery photos equipped with a coach notice for each of the two investigated UI (left: Tappy UI, right: Swipey UI), explaining how to navigate through the gallery

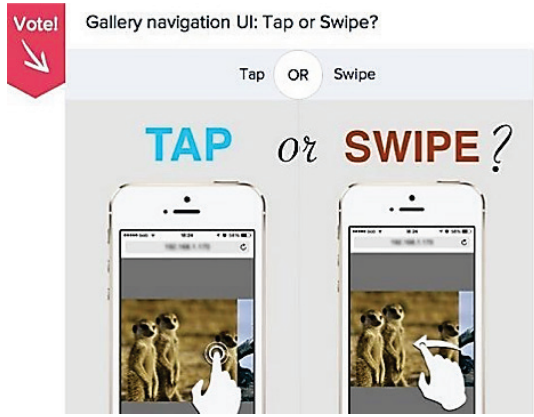

Figure 4 On-line survey on "Gallery navigation UI preference", published on Polar Polls, https://www.polarb.com/

\subsection{Tracking and logging}

For each session, the following data was recorded:

- information about which UI (Tappy or Swipey) was served to the user,

- information whether a coach notice was present or not,

- initial gesture - tap or swipe - for each version,

- total number of photos viewed for each version,

- total number of faulty gestures (gestures that did not invoke any action) for each version.

The above information was tracked using tracking software that was a part of the gallery application and was transmitted to the tracker on the server, where all the information about each session was stored to a log file. Each time information (gesture type, next/prev photo viewed, etc.) was being tracked, a tracker generated an object which also contained a timestamp of the individual occurrences and sent it to the tracker server via tracking pixel, as demonstrated by the example below:

http://trackerUrl.com:5000/pixel.gif?event=\{"ges ture": "tap", "position" : \{ "vertical":"top", "horizo ntal": "right"\}, "sessionId": "74722_1428407539853" , "timestamp" : "2015-04-07T16:09:41.415z
The above request was registered on the server and was written to a $\log$ file. Each subsequent gesture within the same session was appended to that same file.

The presented study focuses on tap vs. swipe comparison only, although the system was able to track and collect a lot of other information, including gesture position on the screen, its direction, timestamp, etc.

Generated log files were analysed using appropriate statistical tools. The results are presented in the Results and Discussion section.

\subsection{Study hypotheses}

The three key questions of our study - and the corresponding hypotheses $(\mathrm{H})$ - were as follows:

1. Which is the preferred way of navigating through a mobile photo gallery: tapping or swiping? We anticipated that using the swipe gesture is more intuitive compared to the tapping (H1).

2. What is the impact of UI's intuitiveness on the number of gallery photos viewed? Our assumption was that more photos are viewed if the more intuitive $\mathrm{UI}$ is used (H2).

3. What is the effect of a coach notice instruction on using the correct/faulty gesture? We hypothesised that showing a coach notice to a user decreases the number of faulty gestures $(\mathrm{H} 3)$.

\section{Results and Discussion}

As can be seen from Tab. 1, out of 435976 users that were exposed to an ad, only 3318 clicked on it, resulting in a CTR of $0,76 \%$. Similarly low rates have been reported in most of the studies on this topic - see e.g. [23, 24]. There were 633 sessions with activity, meaning that at least one user-initiated action (tap, swipe, pinch, rotate, etc.) was logged, while the rest of the users closed the ad immediately. In the presented study we focused on tap and swipe gestures only (574 sessions in total). Results related to our three hypotheses are presented and discussed below.

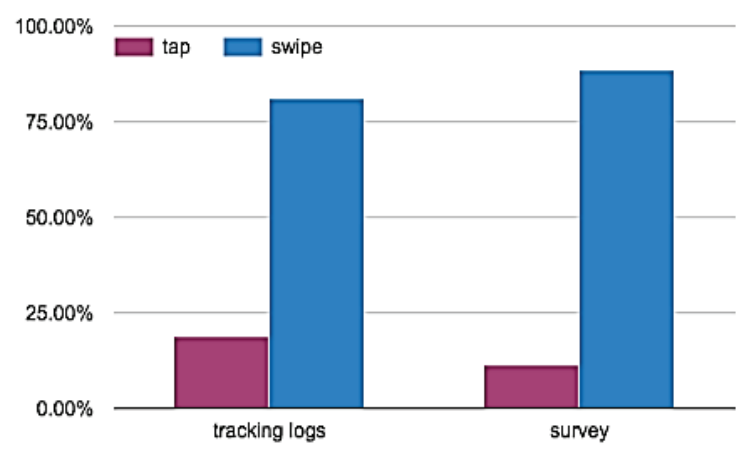

Figure 5 Percentage of swipe and tap gestures: initial user's gesture, obtained from the first experiment (tracking logs; left) and the second experiment (survey answers; right)

Fig. 5 shows the results of the first (left) and the second (right) experiment regarding the preference of the two gestures used for photo gallery navigation (H1). As for the first experiment, only sessions without a coach notice were taken into account so that the gesture's intuitiveness could be assessed. It is evident that swiping 
was much more frequently used as the initial user gesture used to navigate through the gallery (swipe: $79,7 \%$, tap: $20,3 \%$ ). Data obtained from the on-line survey show a similar pattern (swipe: 88,5\%, tap: 11,5\%). Therefore it can be concluded that our first hypothesis has been confirmed: "Using the swipe gesture is more intuitive and preferred to tapping".

Fig. 6 and Tab. 2 contain information about the relationship between the UI type and the mean number of gallery photos viewed by the users (H2). Since we were interested in testing the intuitiveness of the system, only sessions without a coach notice were analysed so a oneway (one factor at two levels: Swipey or Tappy UI) ANOVA was adopted at $95 \%$ confidence level. As the Pvalue was found to be less than 0,05 , there is a statistically significant difference in the mean number of photos viewed between the two investigated UI types, where the more intuitive navigation mode - Swipey UI was evidently characterized by a much higher number of photos viewed (Swipey UI: 5,8, Tappy UI: 2,9). Our second hypothesis was thereby also confirmed.

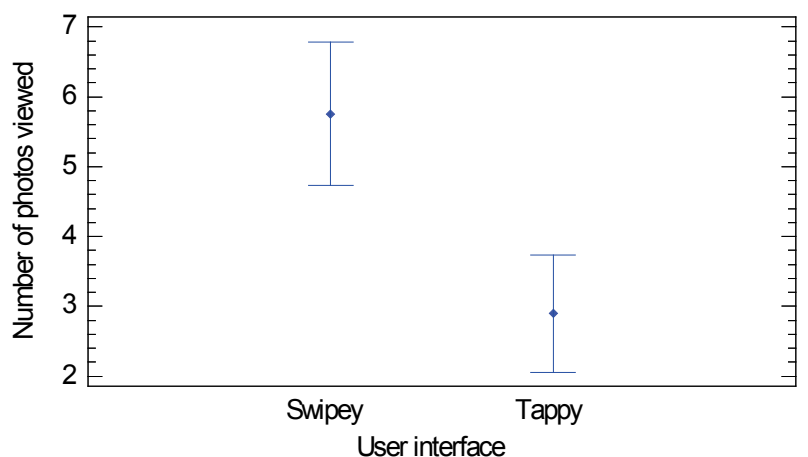

Figure 6 Number of photos viewed for Swipey and Tappy UIs without a coach notice. Lower and upper limits for $95 \%$ LSD intervals are also displayed.

Table 2 ANOVA table for number of photos viewed by UI

\begin{tabular}{|l|c|c|c|c|c|}
\hline \multicolumn{1}{|c|}{ Source } & $\begin{array}{c}\text { Sum of } \\
\text { squares }\end{array}$ & $D f$ & $\begin{array}{c}\text { Mean } \\
\text { square }\end{array}$ & $F$-ratio & $P$-value \\
\hline Between groups & 439,309 & 1 & 439,309 & 9,05 & 0,0029 \\
\hline Within groups & 10733,1 & 221 & 48,5663 & & \\
\hline Total (Corrected) & 11172,5 & 222 & & & \\
\hline
\end{tabular}

Finally, when investigating usability problems (H3), a two-way ANOVA was implemented. Both UI type (Swipey or Tappy UI) as well as a coach notice presence (yes or no) were studied. ANOVA table (Tab. 3) indicates that both factors have statistically significant effects on the number of faulty gestures; their $P$-values are less than 0,05. As shown in Fig. 7, users committed on average a much larger number of faulty gestures per session when served with Tappy UI $(2,20)$ compared to Swipey UI $(0,64)$ and also when not being advised by a coach notice $(1,67)$ compared to the sessions where a coach notice was displayed on their mobile devices $(1,18)$. In addition, $F$ ratio values $(70,6$ compared to 7,1$)$ suggest that the effect of the UI type on the faulty gestures' number is approximately 10-times bigger than that of the coach notice presence.

Although the interaction between the two factors was not found to be statistically significant $(P$-value $=0,24>$ $0,05)$, the corresponding interaction plot (Fig. 8) nevertheless reveals several interesting findings. First, when no coach notice had been presented to the users, a comparatively large number of faulty gestures with Tappy UI was recorded: these users tried to swipe on average 2,34-times per session, which is much more than those users to whom a Swipey UI was served -they tried to incorrectly apply a tap gesture (1,00-time per session). This is in agreement with our above observation that swiping is a more intuitive gesture compared to tapping.

Table 3 ANOVA table for faulty gestures number

\begin{tabular}{|l|c|c|c|c|c|}
\hline \multicolumn{1}{|c|}{ Source } & $\begin{array}{c}\text { Sum of } \\
\text { squares }\end{array}$ & $D f$ & $\begin{array}{c}\text { Mean } \\
\text { square }\end{array}$ & $F$-ratio & $P$-value \\
\hline A: Coach notice & 32,6223 & 1 & 32,6223 & 7,12 & 0,0076 \\
\hline B: User interface & 323,675 & 1 & 323,675 & 70,62 & 0,0000 \\
\hline AB & 6,29817 & 1 & 6,29817 & 1,37 & 0,2411 \\
\hline Residual & 2882,85 & 6299 & 4,58323 & & \\
\hline Total (Corrected) & 3387,37 & 632 & & & \\
\hline
\end{tabular}
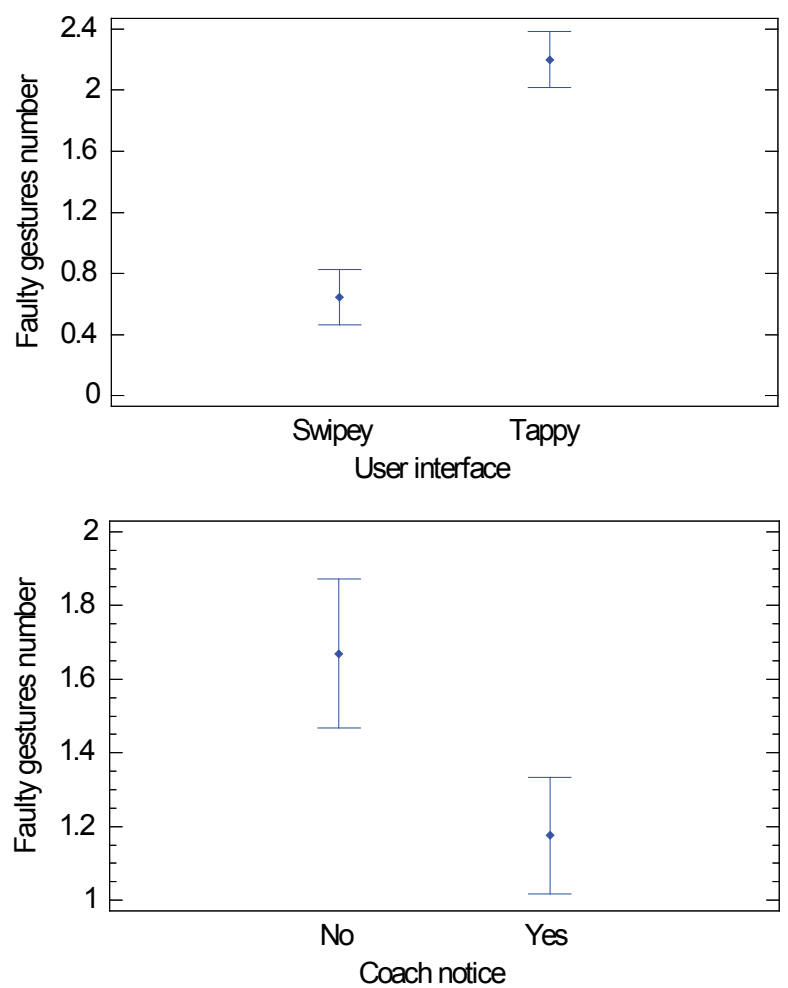

Figure 7 Effect of two factors - UI type (top) and coach notice presence (bottom) - on the faulty gestures' number. Lower and upper limits for 95 $\%$ LSD intervals are also displayed.

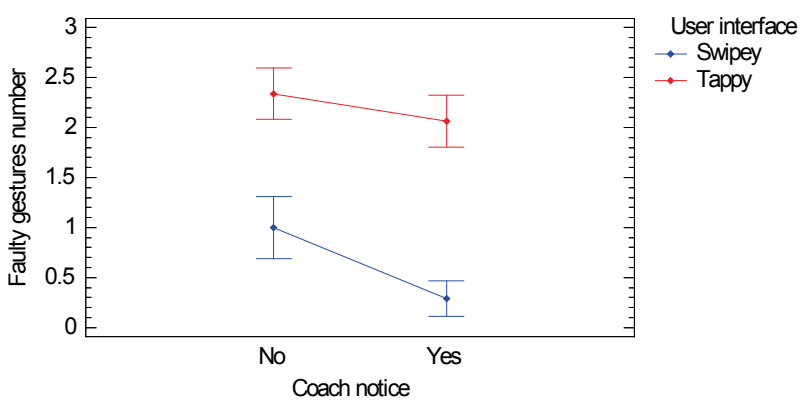

Figure 8 Interaction plot for faulty gestures' number. Lower and upper limits for $95 \%$ LSD intervals are also displayed.

When users were presented with an instruction on how to correctly navigate through the photo gallery (coach notice), the number of faulty gestures committed by a user indeed decreased for both UI types. Interestingly, this reduction was substantially smaller for the Tappy UI (from 2,34 to 2,06) than for the Swipey UI 
(from 1,00 to 0,29). Several explanations can be given for the fact that in spite of being presented with the coach notice many Tappy UI users still applied the faulty swipe - gesture - for navigation: as some previous studies showed, users tend to ignore too intrusive instructions/notices [25]; users prefer swiping to tapping (already confirmed in our study; see discussion regarding H1); users closed the coach notice before they read it; or our coach notice was simply not designed well enough.

We can therefore conclude, that our third hypothesis was confirmed as well: the presence of a coach notice in general decreases usability problems by reducing the number of faulty gestures.

\section{Conclusion}

According to our study, the preferred users' way for navigating a mobile photo gallery was by swiping images and designers to improve the user experience can use these findings. Use of tapping should be limited to special scenarios, such as opening a modal dialog with gallery specific features, allowing users to save an image, or share it via a social network.

Tracking users' behaviour through log files and their analysis have given us insightful information and is arguably faster and more cost efficient than traditional usability testing, although in an ideal scenario, both should be performed to maximize the understanding of users' behaviour.

The coach notice turned out to be useful, but as the effects of the coach notice did not entirely meet our expectations in reducing the number of faulty gesture with a less intuitive UI (Tappy UI), we suggest a further investigation to find a better design solution for presenting a coach notice and improve usability.

Only a fraction of users that are exposed to an ad decide to click on it, and even those may be quickly driven away, due to the content or if the UI is not well thought of and properly designed to be useful for interaction. Therefore, we can expect more research effort to be put into experimentation with different UIs to yield a better user experience.

Our system is very lightweight, but easily adjustable and can be used for several other studies; not only investigation of behaviour for mobile photo gallery navigation, but for other patterns that are present in mobile content as well.

\section{References}

[1] Böhmer, M.; Hecht, B.; Schöning, J.; Krüger, A.; Bauer, G. Falling asleep with Angry Birds, Facebook and Kindle: a large scale study on mobile application usage. // ACM Proceedings of the $13^{\text {th }}$ international conference on Human computer interaction with mobile devices and services / Stockholm, 2011, pp. 47-56.

[2] Hoober, S. How do Users Really Hold Mobile Devices? UX matters. 2013. http://www.uxmatters.com/ mt/archives/2013/02/how-do-users-really-hold-mobiledevices.php (10.7.2015).

[3] Lógó, E.; Petruska, I. An Empirical Study from Industrial Design Engineering Students' Product Experiences with Intelligent Every Day Used Product. // Acta Polytechnica Hungarica. 11, 1(2014), pp. 173-192.
[4] Hilera, J. R.; Fernandez-Sanz, L.; Misra, S. Present and future of Web content accessibility: An analysis. // Tehnički vjesnik. 20, 1(2013), pp. 35-42.

[5] De Angeli, A.; Sutcliffe, A.; Hartmann, J. Interaction, usability and aesthetics: what influences users' preferences? $/ /$ ACM Proceedings of the $6^{\text {th }}$ conference on Designing Interactive systems / Chicago, 2006, pp. 271-280.

[6] Tractinsky, N. Aesthetics and Apparent Usability: Empirically Assessing Cultural and Methodological Issues. // ACM CHI Proceedings of the SIGCHI Conference on Human factors in computing system, 1997, pp. 115-122.

[7] O'Brian, H.; Toms, E. What is user engagement? A conceptual framework for defining user engagement with technology. // Journal of the American Society for Information Science and Technology. 59, 6(2008), pp. 938955. DOI: 10.1002/asi.20801

[8] Calder, B. J.; Malthouse, E. C.; Schaedel, U. An Experimental Study of the Relationship between Online Engagement and Advertising Effectiveness. // Journal of Interactive Marketing. 23, 4(2009), pp. 321-331. DOI: 10.1016/j.intmar.2009.07.002

[9] Attfield, S.; Kazai, G.; Lalmas, M.; Piwowarski, B. Towards a science of user engagement (position paper). // WSDM Workshop on User Modelling for Web Applications / Hong Kong, 2011.

[10] Dániel, B.; Korondi, P.; Sziebig, G.; Thomessen, T. Evaluation of flexible graphical user interface for intuitive human robot interactions. // Acta Polytechnica Hungarica. 11, 1(2014), pp. 135-151.

[11] Page, T. Skeuomorphism or flat design: future directions in mobile device User Interface (UI) design education. // International Journal of Mobile Learning and Organisation. 8, 2(2014), pp. 130-142. DOI: 10.1504/IJMLO.2014.062350

[12] Tchankue, P.; Wesson, J.; Vogts, D. The impact of an adaptive user interface on reducing driver distraction. // ACM Proceedings of the $3^{\text {rd }}$ International Conference on Automotive User Interfaces and Interactive Vehicular Applications / Salzburg, 2011, pp. 87-94.

[13] IAB internet advertising revenue report, 2014 full year results. $2015 . \quad \mathrm{http}: / / \mathrm{www}$. iab.net/media/file/ IAB Internet Advertising Revenue FY 2014.pdf (10.7.2015)

[14] Negulescu, M.; Ruiz, J.; Li, Y.; Lank, E. Tap, swipe, or move: attentional demands for distracted smartphone input. // ACM Proceedings of the International Working Conference on Advanced Visual Interfaces. / Capri Island (Naples), 2012, pp. 173-180.

[15] Leitão, R. Creating mobile gesture-based interaction design patterns for older adults: A study of tap and swipe gestures with Portuguese seniors (MSc Thesis). // Porto: Faculdade de Engenharia da Universidade do Porto, 2012.

[16] Law, E. L. C.; Roto, V.; Hassenzahl, M.; Vermeeren, A. P.; Kort, J. Understanding, scoping and defining user experience: a survey approach. // ACM Proceedings of the SIGCHI Conference on Human Factors in Computing Systems / Boston, 2009, pp. 719-728.

[17] Duh, H. B. L.; Tan, G. C.; Chen, V. H. H. Usability evaluation for mobile device: a comparison of laboratory and field tests. // ACM Proceedings of the $8^{\text {th }}$ conference on Human-computer interaction with mobile devices and services / Helsinki, 2006, pp. 181-186.

[18] Obrist, M.; Roto, V.; Väänänen-Vainio-Mattila, K. User experience evaluation: do you know which method to use? // ACM CHI Extended Abstracts on Human Factors in Computing Systems / Boston, 2009, pp. 2763-2766.

[19] Akers, D.; Jeffries, R.; Simpson, M.; Winograd, T. Backtracking Events as Indicators of Usability Problems in Creation-Oriented Applications. // ACM Transactions on Computer-Human Interaction (TOCHI). 19, 2(2012), pp. 16.1-14.40 
[20] Spool, J.; Schroeder, W. Testing web sites: Five users is nowhere near enough. // ACM CHI'01 extended abstracts on Human factors in computing systems / Seattle, 2001, pp. 285-286.

[21] Nielsen, J. Cost of user testing a website. Nielsen Norman Group. 1998. URL: http://www.nngroup.com/articles/costof-user-testing-a-website/ (10.7.2015).

[22] Google AdWords - Online Advertising by Google. 2015. URL: https://adwords.google.com (10.7.2015).

[23] Nielsen, J. Methodology weaknesses in Poynter Eyetrack Study. Nielsen Norman Group. 2000. URL: http://www.nngroup.com/articles/methodologyweaknesses-poynter/ (10.7.2015).

[24] Hofacker, C. F.; Murphy, J. World Wide Web banner advertisement copy testing. // European Journal of Marketing. 32, 7/8(1998), pp. 703-712. DOI: 10.1108/03090569810224092

[25] Andersen, E.; O'Rourke, E.; Liu, Y.-E.; Snider, R.; Lowdermilk, J.; Truong, D.; Cooper, S.; Popovic, Z. The impact of tutorials on games of varying complexity. // ACM CHI '12 Proceedings of the SIGCHI Conference on Human Factors in Computing Systems / Austin, 2012, pp. 59-68.

\section{Authors' addresses}

\section{Robert Sedovšek, Ph.D. student}

University of Ljubljana, Faculty of Natural Sciences and Engineering, Department of Textiles, Graphic Arts and Design Snežniška 5, 1000 Ljubljana, Slovenia

E-mail: robert.Sedovsek@gmail.com

\section{Assoc. prof. dr. sc. Matevž Pogačnik}

Laboratory for Telecommunications. Faculty of Electrical

Engineering, University of Ljubljana

Tržaška cesta 25, 1000 Ljubljana, Slovenia

E-mail: matevz.pogacnik@fe.uni-lj.si

Assoc. prof. dr. sc. Aleš Hladnik, Corresponding author University of Ljubljana, Faculty of Natural Sciences and Engineering, Department of Textiles, Graphic Arts and Design Snežniška 5, 1000 Ljubljana, Slovenia

E-mail: ales.hladnik@ntf.uni-lj.si 